\title{
ANTHOPORIA, A NEW GENUS IN THE POLYPORALES (AGARICOMYCETES)
}

\author{
DARIUSZ KARASIŃSKi \& TUOMO NiEMELÄ
}

\begin{abstract}
A new genus, Anthoporia Karasiński \& Niemelä, is proposed for the brown-rot polypore Polyporus albobrunneus Romell [= Antrodia albobrunnea (Romell) Ryvarden]. The new genus is separated from Antrodia P. Karst. s.str. in several morphological features, and it is only distantly related to Antrodia serpens (Fr.) P. Karst. (generic type of Antrodia) in recently published phylogenies. Additionally, Anthoporia albobrunnea (Romell) Karasiński \& Niemelä is described and illustrated based on material collected in Białowieża National Park in northeastern Poland.
\end{abstract}

Key words: Antrodia albobrunnea, Białowieża Primeval Forest, polypores, systematics, wood-inabiting fungi

Dariusz Karasiński, Department of Mycology, W. Szafer Institute of Botany, Polish Academy of Sciences, Lubicz 46, $31-512$ Kraków, Poland; e-mail: d.karasinski@botany.pl

Tuomo Niemelä, Botany Unit, Finnish Museum of Natural History, P.O. Box 7, FI-00014 Helsinki, Finland; e-mail: tuomo. niemela@helsinki.fi

\section{INTRODUCTION}

Polyporales is one of the largest orders of the class Agaricomycetes (Basidiomycota) including ca 1800 species, 150 genera and 40 described families (Hibbett et al. 2014). It contains species having pileate, pileate-stipitate, multiple flabelliform or resupinate basidiomata with a poroid, hydnoid, lamellate, merulioid or smooth hymenophore, and a monomitic, dimitic and trimitic hyphal system. Members of the order are mainly wood-decomposers causing white or brown rot. A broad overview of the Polyporales, based on phylogenetic and phylogenomic analyses, was recently given by Binder et al. (2013), who divided the order into four major lineages called residual polyporoid, phlebioid, antrodia and core polyporoid clades. The antrodia clade, which was first identified and introduced by Hibbett and Donoghue (2001), includes only species that produce a brown-rot type of decay. Pileate and resupinate polypores are predominant in the clade. Generic delimitation in the antrodia clade is highly problematic, as shown by Ortiz-Santana et al. (2013) in an investigation of relationships among members of the clade, using 123 species representing
26 traditionally accepted genera. They showed that many of these genera are poly- or paraphyletic and in need of a generic reclassification.

The genus Antrodia P. Karst. (Polyporales) was described by Karsten (1879) and later redefined by Donk (1960, 1966), who selected Daedalea serpens Fr. as its type. Antrodia in the broad sense is one of the largest genera of polypores, including ca 50 species (Kirk et al. 2008) which cause brown rot, have a dimitic hyphal system with clamped generative hyphae, colorless skeletal hyphae, no cystidia, smooth, non-amyloid basidiospores, and resupinate to effused-reflexed basidiomata (Ryvarden 1991; Ryvarden \& Gilbertson 1993; Ryvarden \& Melo 2014). Phylogenetic studies revealed that Antrodia s.l. is not monophyletic but scattered in groups among other genera of brown-rot polypores such as Fomitopsis P. Karst, Daedalea Pers., Melanoporia Murrill and Rhodonia Niemelä (Kim et al. 2001, 2003; Wu et al. 2004; Chiu 2007; Yu et al. 2010; Rajchenberg et al. 2011; Spirin et al. 2013a, b, 2015). So far the most comprehensive study of the relationships between Antrodia and related taxa is the one 
by Ortiz-Santana et al. (2013), but this study was focused on the whole antrodia clade. Members of the clade were grouped into five main groups. One of them, called the 'core antrodia group', contains the vast majority of broadly defined Antrodia species mixed with other taxa of brown-rot polypores. More than 30 species of Antrodia s.l. included in the analysis formed several terminal groups offering a basis for generic reclassification.

Recently an epitype for Antrodia serpens (Fr.) P. Karst. was designated by Spirin et al. (2013b), and the genus Antrodia was defined in the strict sense based on morphological and molecular data. According to phylogenetic analyses, Antrodia s.str. contains only seven species grouped around Antrodia serpens (Spirin et al. 2013b; Chen \& Cui 2016). All phylogenetic studies showed that the basal position in the core antrodia group, distant from Antrodia serpens, is occupied by Antrodia albobrunnea (Romell) Ryvarden, and no generic name is available for this species. Therefore, in this work a new genus Anthoporia is proposed to accommodate this species, which is also described and illustrated based on material collected in Białowieża National Park in northeastern Poland.

\section{MATERIAL AND METHODS}

The specimens examined were collected in Białowieża National Park in 2009-2011. Dry specimens are preserved in KRAM. For morphological studies, thin freehand sections from fresh or dry basidiomata were made under a Nikon SMZ-2T microscope using a razor blade, mounted in water, $3 \%(\mathrm{wt} / \mathrm{vol})$ aqueous potassium hydroxide and $1 \%(\mathrm{wt} / \mathrm{vol})$ aqueous phloxine, and Melzer's reagent or $0.1 \%$ Cotton Blue (wt/vol) in $60 \%(\mathrm{wt} / \mathrm{vol})$ lactic acid, and examined under a Nikon Eclipse E-400 light microscope. In presenting the variation of basidiospore size, $5 \%$ of the measurements were excluded from each end of the range and are given in parentheses. The following abbreviations are used in the species description: $\mathrm{L}$ - mean basidiospore length, $\mathrm{W}$ - mean basidiospore width, $\mathrm{Q}$ - mean length/width ratio, $\mathrm{n}=$ number of measurements per specimen. Color photographs were taken by D. K. using a Nikon D200 camera and AF Micro Nikkor $60 \mathrm{~mm} \mathrm{1:2.8} \mathrm{D} \mathrm{lens.}$ Herbarium acronyms follow Index Herbariorum (http://sweetgum.nybg.org/ih/).

\section{TAXONOMY}

Anthoporia Karasiński \& Niemelä, gen. nov. TYPE: Polyporus albobrunneus Romell.

MycoBank no.: MB 816285

Basidiomata annual to perennial, resupinate, effused, soft, with cottony subiculum and fimbriate margin. Rhizomorphs present but inconspicuous. Hymenophore poroid. Hyphal system dimitic. Generative hyphae with clamp connections, in subiculum and tube trama hyaline, in basal subiculum close to substrate brown, often with resinous or fine crystalline encrustation, and occasional simple septa. Skeletal hyphae thick-walled to almost solid, not reacting in $\mathrm{KOH}$, Melzer's reagent or Cotton Blue. Basidia clavate with four sterigmata and basal clamp. Cystidia absent. Basidiospores cylindrical to suballantoid, thin-walled, smooth, non-amyloid, acyanophilous.

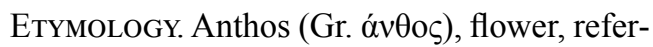
ring to the fragrant smell. Poria, a general name of resupinate polypores.

Anthoporia albobrunnea (Romell) Karasiński \& Niemelä, comb. nov.

Figs 1-3

Basionym: Polyporus albobrunneus Romell, Arkiv för Botanik 11(3): 10. 1911.

MycoBank no.: MB 816287

Basidiomata annual to perennial, resupinate, effused, forming elliptical or irregular patches 3-40 cm long and 1-8 cm wide, or sometimes larger when confluent, up to $9 \mathrm{~mm}$ thick, soft when fresh, with pleasant floral smell, reminiscent also of dried apples, taste mild. Subiculum cottony, up to $1.5 \mathrm{~mm}$ thick, on section white to pale ochraceous, with brown zone next to substrate. Pore surface at first greyish white, later becoming creamcolored to greyish brown, in mature specimens often with cinnamon brown discolored patches in some places. Senescent specimens dull cinnamon brown. Sterile margin always present and distinct, cottony-fimbriate, usually $c$ a $2-3 \mathrm{~mm}$ wide, occasionally wider up to $7 \mathrm{~mm}$, initially white, more or less brownish or rusty brown with age. Pores 3-5 per mm, round to angular; occasionally larger, elongated pores up to $1 \mathrm{~mm}$ in diameter are pre- 


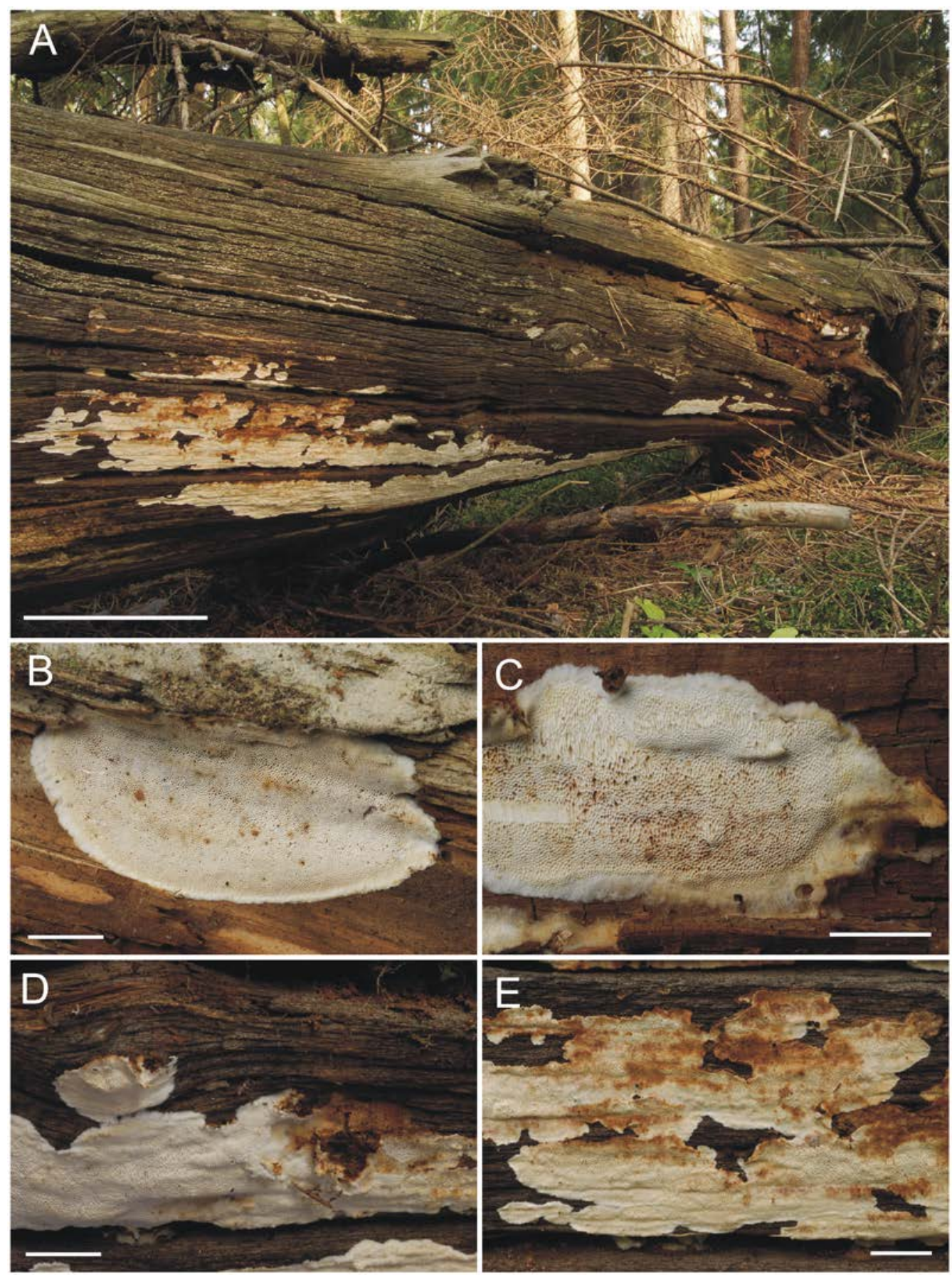

Fig. 1. Anthoporia albobrunnea (Romell) Karasiński \& Niemelä. A - basidiomata on large fallen Pinus sylvestris log (Karasiński 6356), B - young basidiome with white margin (Karasiński 6405), C - mature basidiome with partly brownish marginal zone (Karasiński 6366), D - specimen Karasiński 6009, E - confluent basidiomata with brown discoloring patches (Karasiński 6356). Scale bars: $\mathrm{A}=10 \mathrm{~cm}, \mathrm{~B}-\mathrm{E}=1 \mathrm{~cm}$. 

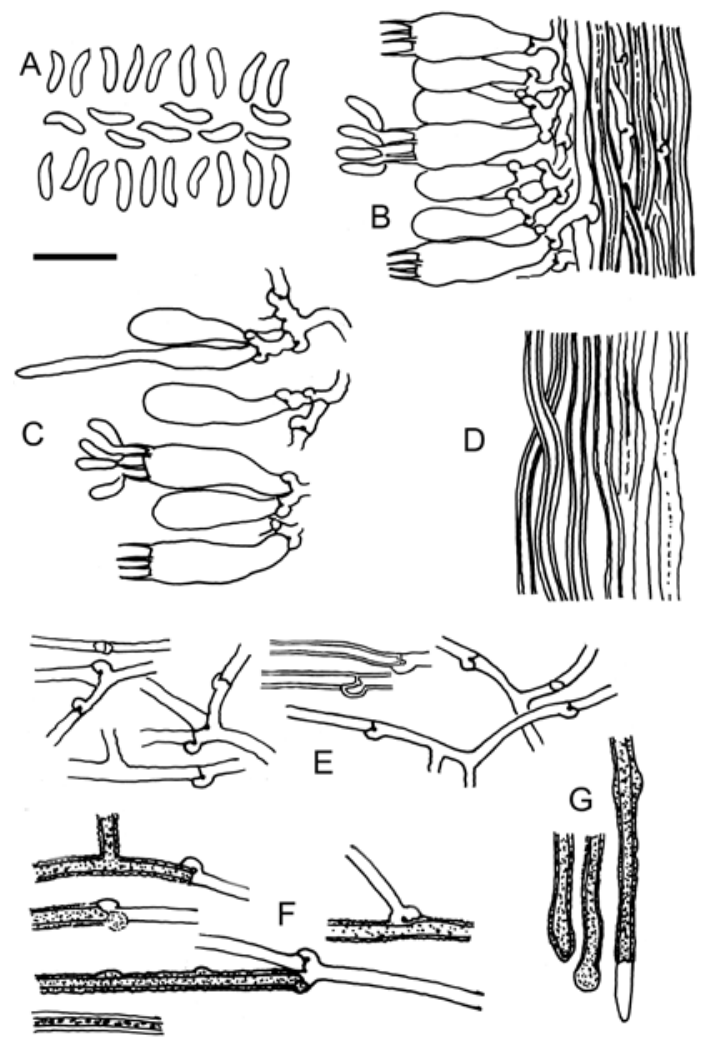

Fig. 2. Anthoporia albobrunnea (Romell) Karasiński \& Niemelä drawn from Karasiński 6356. A - basidiospores, B - part of hymenium and tube trama, C - hymenial cells: basidia, basidioles and one cystidium-like element with elongated, hyphoid apex, D - skeletal hyphae from tube trama, E - generative hyphae, F - brown hyphae from upper subiculum, $\mathrm{G}$ - ends of brown hyphae from margin of basidiome. Scale bar $=10 \mu \mathrm{m}$.

sent. Dissepiments thin, slightly uneven, finely minutely fimbriate under lens. Tubes $0.5-2.0 \mathrm{~mm}$ long, initially concolorous with pore surface, later slightly darker, cream ochraceous to pale brown. Hyphal structure dimitic. Generative hyphae of two kinds: (1) in subhymenium, tube trama and subiculum proper thin to slightly thick-walled, hyaline, smooth, 1.8-4.0 $\mu \mathrm{m}$ wide, with clamps at all septa; (2) in upper subiculum (basal layer) next to substrate and at marginal zone 2.2-4.6 $\mu \mathrm{m}$ wide, thick-walled with distinct lumen, brown and sometimes covered with brownish resinous matter or very fine crystals, with clamps and scattered simple septa; single hyphae of this kind rarely pre- sent in subiculum proper, and along dissepiment edges. At margin of basidiome, brown-pigmented generative hyphae are sometimes glued together, forming small hyphal cords (rhizomorphs). Skeletal hyphae 2.0-4.6 $\mu \mathrm{m}$ wide, thick-walled to solid, hyaline; in tube trama more or less parallel, in subiculum loosely arranged and interwoven in various directions. Cystidia absent, but in some specimens cystidiole-like hymenial cells with elongated and projecting apices are rarely seen. Basidia 14-18 $\times$ 4.5-5.5 $\mu \mathrm{m}$, clavate, with basal clamp and 4 sterigmata up to 6 um long. Basidiospores (5.0-)5.4 $6.8(-7.2) \times(1.4-) 1.6-1.8(-2.0) \mu \mathrm{m}(\mathrm{n}=150 / 5)$, $\mathrm{L}=5.82, \mathrm{~W}=1.72, \mathrm{Q}=3.12-4.42$, cylindrical to suballantoid, with rounded distal end and tapering towards apiculus, thin-walled, smooth, hyaline, rarely with a few small oil droplets, inamyloid, acyanophilous.

Specimens eXamined: Poland. Podlasie Province: Białowieża National Park (BNP), forest section 256, $52^{\circ} 46^{\prime} 05.9^{\prime \prime} \mathrm{N}, 23^{\circ} 51^{\prime} 35.8^{\prime \prime} \mathrm{E}$, in spruce-pine forest of primeval origin, on underside of well rotted log of Pinus sylvestris, 29 July 2009, leg. D. Karasiński 3624 (KRAM F-58391); BNP, forest section 374, $52^{\circ} 43^{\prime} 27.5^{\prime \prime} \mathrm{N}, 23^{\circ} 54^{\prime} 39.8^{\prime \prime} \mathrm{E}$, in mixed forest (TilioCarpinetum with Picea abies and Pinus sylvestris), on Pinus sylvestris fallen log, 23 Sept. 2010, leg. D. Karasiński 6009 (KRAM F-58392); BNP, forest section $374,52^{\circ} 43^{\prime} 24.6^{\prime \prime} \mathrm{N}, 23^{\circ} 54^{\prime} 35.2^{\prime \prime} \mathrm{E}$, in mixed forest (Tilio-Carpinetum with Picea abies and scattered Pinus), on Pinus sylvestris fallen log, 21 Sept. 2011, leg. D. Karasiński 6405 (KRAM F-58395); BNP, forest section $256,52^{\circ} 46^{\prime} 07.6^{\prime \prime} \mathrm{N}, 23^{\circ} 51^{\prime} 40.1^{\prime \prime} \mathrm{E}$, in pine-spruce forest of primeval origin, on Pinus sylvestris fallen log, 19 Sept. 2011, leg. D. Karasiński 6356 (KRAM F-58393); BNP, forest section $256,52^{\circ} 46^{\prime} 09.2^{\prime \prime} \mathrm{N}$, $23^{\circ} 51^{\prime} 42.1^{\prime \prime} \mathrm{E}$, in pine-spruce forest of primeval origin, on Pinus sylvestris fallen log fragment, 19 Sept. 2011, leg. D. Karasiński 6366 (KRAM F-58239).

Distribution AND ECOLOGY. Anthoporia albobrunnea has a northern circumpolar distribution pattern and is known from North America and Eurasia (Gilbertson \& Ryvarden 1986; Núñez \& Ryvarden 2001; Ryvarden \& Melo 2014). In North America the species was recorded in the western United States, western Canada and Alaska (Gilbertson \& Ryvarden 1986). In Asia it is reported from the Changbai Reserve in 

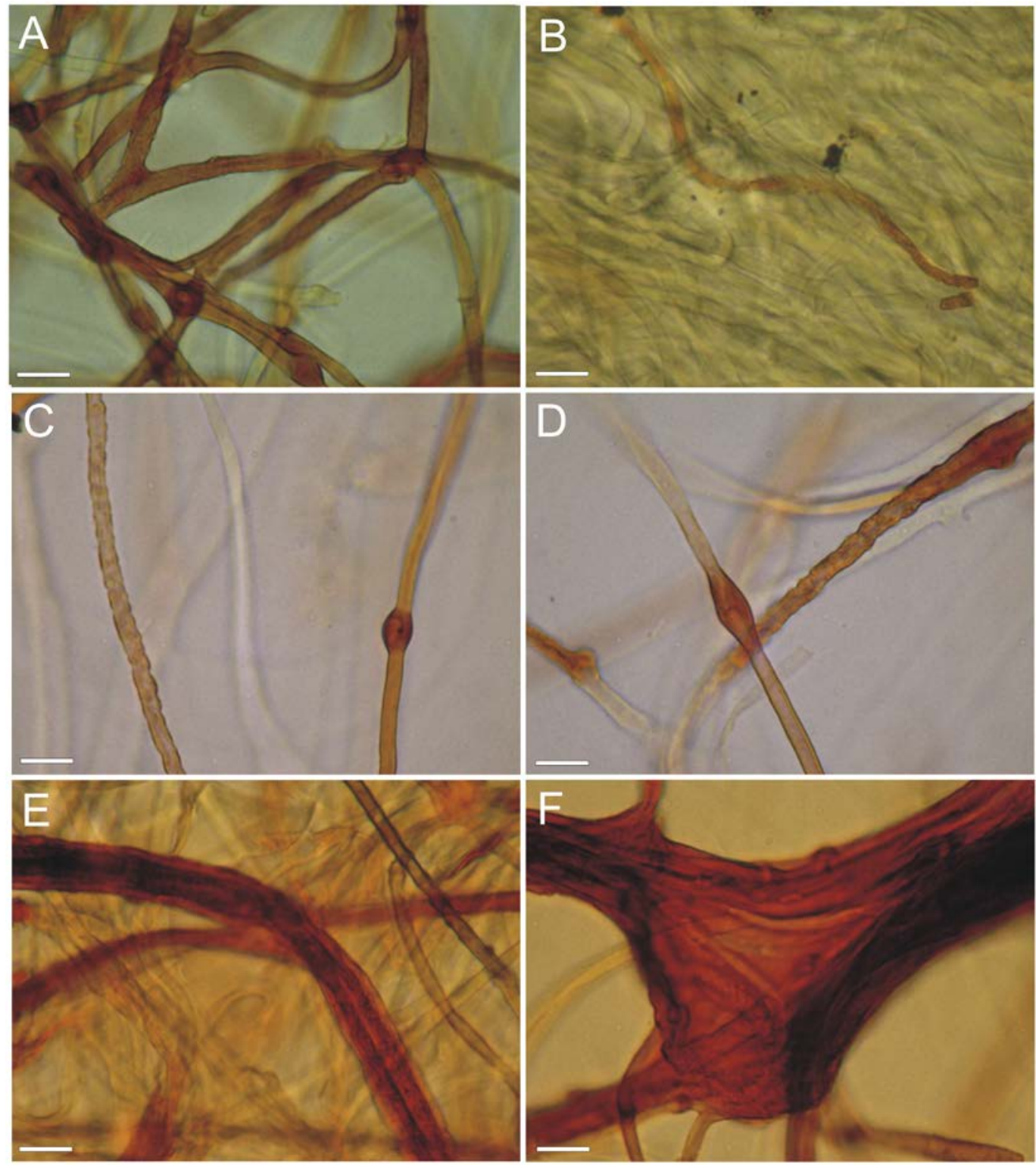

Fig. 3. Micrographs of Anthoporia albobrunnea (Romell) Karasiński \& Niemelä: A - brown hyphae from margin of basidiome, B - single brown hypha among generative and skeletal hyphae in subiculum, C - brown hyphae from margin, covered by crystalline matter (left) and with drop of resinous matter around clamp (right), D - brown hyphae with resinous and crystalline encrustation, E \& F - hyphal cords (rhizomorphs) from margin of basidiome (all from Karasiński 6356). Scale bars $=10 \mu \mathrm{m}$.

northern China (Núñez \& Ryvarden 2001) and Central Ural (Asian part of Russia) (Kotiranta et al. 2007). In Europe Anthoporia albobrunnea is rather rare and has its major distribution in Northern Europe: Norway (Ryvarden et al. 2003),
Sweden (Eriksson 1958) and Finland (Kotiranta et al. 2009). For example, in Finland A. albobrunnea is frequent in the Northern Boreal zone (Kotiranta et al. 2009). Only single records are from other European countries: Belarus, Poland, 
Spain and former Yugoslavia (Komarova 1964; Ryvarden \& Melo 2014). In Poland it was reported only from Białowieża National Park (Karasiński \& Wołkowycki 2015). The species is associated with old-growth and natural coniferous and mixed forests, being very sensitive to disturbance, in particular to removal of kelo trees (standing dead pines) (Niemelä et al. 2002). In Finland this species is regarded as one of the best indicators of long continuity in old-growth forests. In Fennoscandia and Central Europe the species is known almost exclusively on Pinus, but from Central Ural it was reported more often on Picea (Kotiranta et al. 2007). All Polish specimens reported here were collected on big fallen logs of Pinus sylvestris in intermediate or advanced stages of decomposition, lying on the ground or partly hanging over the forest floor. The specimens examined were found in a terminal-stage primeval pine-spruce forest with a quite open tree stand structure, and in mature Tilio-Carpinetum with Picea abies and single Pinus sylvestris trees.

\section{DISCUSSION}

Anthoporia differs significantly from the description of Antrodia s.str. provided by Spirin et al. (2013b). The latter genus has large pedunculate basidia, large cylindrical to narrow ellipsoid basidiospores, thick-walled hymenial cells, hyphidia and rare skeletocystidia; the basidiomata are usually effused-reflexed to pileate (exceptionally resupinate), leathery to corky, often hard, with a rather dense and compact subiculum. Anthoporia has short clavate basidia which are less than $20 \mu \mathrm{m}$ long (20-50 $\mu \mathrm{m}$ long in Antrodia), and shorter, narrower basidiospores, up to $7 \times$ $2 \mu \mathrm{m}$ (ca 6.5-12.0 × 3-6 $\mu \mathrm{m}$ in Antrodia). Thickwalled hymenial cells, hyphidia or skeletocystidia are not observed in Anthoporia (in some specimens hymenial cells with elongated hyphoid ends are sometimes present, though usually they are lacking). The basidiomata of Anthoporia are totally resupinate, soft, with a cottony subiculum consisting of loosely arranged hyphae. Finally, Anthoporia differs from Antrodia in having brown generative hyphae in the upper subiculum (basal layer) next to the substrate and at the margin of the basidiome.

In relation to other species of Antrodia s.l., Anthoporia albobrunnea is reminiscent of resupinate specimens of Antrodia serialis (Fr.) Donk in having an ochraceous to brown margin of the basidiomata. However, Antrodia serialis is usually effused-reflexed, with imbricate and elongated pilei, a leathery consistency, larger pores, and larger, subfusiform basidiospores. Moreover, phylogenetically this species is not closely related to Anthoporia (Binder et al. 2013; Ortiz-Santana et al. 2013). In the shape and size of basidiospores, Anthoporia albobrunnea conforms with some species of Antrodia s. lato that are now assigned to Amyloporia Bondartsev \& Singer, especially to A. xantha (Fr.) Bondartsev \& Singer (generitype of Amyloporia). Anthoporia differs completely from Amyloporia xantha in basidiome structure. The latter has skeletal hyphae with amyloid reaction and basidiomata with a bitter taste and chalky consistency. Moreover, Amyloporia xantha (together with some related species) is phylogenetically distant from Anthoporia albobrunnea (Cui \& Dai 2013; Ortiz-Santana et al. 2013).

The presence of hyphal cords at the margin of the basidiomata of Anthoporia albobrunnea was not observed before in this species. These hyphal cords may be interpreted as inconspicuous rhizomorphs. In this character, Anthoporia somewhat resembles Fibroporia Parmasto, a monophyletic genus as confirmed by recent phylogenetic studies (Rajchenberg et al. 2011; Bernicchia et al. 2012; Ortiz-Santana et al. 2013; Chen et al. 2015). However, Fibroporia species form distinct, white or yellow rhizomorphs, have ellipsoid and slightly thick-walled basidiospores, and the genus is phylogenetically distinct from Anthoporia. Fibroporia occupies a basal position, sister to all other lineages of the antrodia clade (Ortiz-Santana et al. 2013).

All recently published molecular phylogenies have shown Anthoporia albobrunnea to be only distantly related to Antrodia, Amyloporia and Fibroporia, and this is also supported by the morphological characteristics outlined in this work. 
ACKNOWLEDGEMENTS. We thank the anonymous reviewers for helpful remarks on the manuscript. This work was supported in part by statutory funds of the W. Szafer Institute of Botany, Polish Academy of Sciences, Kraków.

\section{REFERENCES}

Bernicchia A., Gorjón S. P., Vampola P., Ryvarden L. \& Prodi A. 2012. A phylogenetic analysys of Antrodia s.1. based on nrDNA ITS sequences, with emphasis on rhizomorphic European species. Mycol. Progr. 11: 93-100.

Binder M., Justo A., Riley R., Salamov A., Sjökvist E., Copeland A., Foster B., Sun H., Larsson E., Larsson K. H., Townsend J., Grigoriev I. V. \& Hibbett D. S. 2013. Phylogenetic and phylogenomic overview of the Polyporales. Mycologia 105: 1350-1373.

Chen Y. Y. \& CUi B. K. 2016. Phylogenetic analysis and taxonomy of the Antrodia heteromorpha complex in China. Mycoscience 57: 1-10.

Chen Y. Y., Li H. I. \& Cui B. K. 2015. Molecular phylogeny and taxonomy of Fibroporia (Basidiomycota) in China. Phytotaxa 203: 47-54.

Chiu H. H. 2007. Phylogenetic analysis of Antrodia species and Antrodia camphorata inferred from internal transcribed spacer region. Antonie van Leeuwenhoek 91: 267-276.

Cui B. K. \& DAI Y. C. 2013. Molecular phylogeny and morphology reveal a new species of Amyloporia (Basidiomycota) from China. Antonie van Leeuwenhoek 104: 817-827.

Donk M. A. 1960. The generic names proposed for Polyporaceae. Persoonia 1: 173-302.

Donk M. A. 1966. Notes on European polypores - I. Persoonia 4: 337-343.

ERIKSSON J. 1958. Studies in the Heterobasidiomycetes and Homobasidiomycetes-Aphyllophorales of Muddus National Park in North Sweden. Symb. Bot. Upsal. 16(1): $1-172,24$ pls.

Gilbertson R. L. \& Ryvarden L. 1986. North American Polypores. 1. Fungiflora, Oslo.

Hibbett D. S., Bauer R., Binder M., Giachini A. J., HoSAKa K., Justo A., Larsson E., Larsson K. H., Lawrey J. D., Miettinen O., Nagy L. G., Nilsson R. H., Weiss M. \& Thorn R. G. 2014. Agaricomycetes. In: D. J. MaLaughlin \& J. W. Spatafora (eds), The Mycota VII, Part A. Systematics and Evolution, Second Edition, pp. 373-429. Springer-Verlag, Berlin - Heidelberg.

Hibbett D. S. \& Donoghue M. J. 2001. Analysis of character correlations among wood-decay mechanisms, mating system and substrate ranges in Homobasidiomycetes. Syst. Biol. 50: 215-242.
KARASIŃSKI D. \& WOŁKOWYCKI M. 2015. An annotated and illustrated catalogue of polypores (Agaricomycetes) of the Białowieża Forest. Polish Bot. J. 60: 217-292.

Karsten P. A. 1879. Symbolae ad mycologiam fennicam 6. Meddeland. Soc. Fauna Fl. Fenn. 5: 15-46.

Kim S. Y., PARK S. Y. \& Jung H. S. 2001. Phylogenetic classification of Antrodia and related genera based on ribosomal RNA internal transcribed spacer sequences. J. Microbiol. Biotechnol. 11: 475-481.

Kim S. Y., Park S. Y., Ko K. S. \& Jung H. S. 2003. Phylogenetic analysis of Antrodia and related taxa based on partial mitochondrial SSU rDNA sequences. Antonie van Leeuwenhoek 83: 81-88.

Kirk P. M., Cannon P. F., Minter D. W. \& Stalpers J. A. 2008. Ainsworth \& Bisby's Dictionary of the Fungi. 10 ed. CAB International, Wallingfort, Oxon.

Komarova E. P. 1964. Opredelitel'trutovykh gribov Belorussii. Izdatel'stvo "Nauka i Tekhnika", Minsk.

Kotiranta H., Saarenoksa R. \& Kytövuori I. 2009. Aphyllophoroid fungi of Finland. A check-list with ecology, distribution, and threat categories. Norrlinia 19: 1-223.

Kotiranta H., Ushakova N. \& Mukhin V. A. 2007. Polypore (Aphyllophorales, Basidiomycetes) studies in Russia. 2. Central Ural. Ann. Bot. Fenn. 44: 103-127.

Niemelä T., Wallenius T. \& Kotiranta H. 2002. The kelo tree, a vanishing substrate of specified wood-inhabiting fungi. Polish Bot. J. 47: 91-101.

NúÑez M. \& Ryvarden L. 2001. East Asian Polypores. 2. Synopsis Fungorum 14. Fungiflora, Oslo.

Ortiz-Santana B., Lindner D. L., Miettinen O., Justo A. \& HibbetT D. S. 2013. A phylogenetic overview of the antrodia clade (Basidiomycota, Polyporales). Mycologia 105: 1391-1411.

Rajchenberg M., Gorjón S. P. \& Pildain M. B. 2011. The phylogenetic disposition of Antrodia s.l. (Polyporales, Basidiomycota) from Patagonia, Argentina. Austral. Syst. Bot. 24: 111-120.

Ryvarden L. 1991. Genera of Polypores. Nomenclature and taxonomy. Synopsis Fungorum 5. Fungiflora, Oslo.

Ryvarden L. \& Gilbertson R. L. 1993. European Polypores. 1. Synopsis Fungorum 6. Fungiflora, Oslo.

Ryvarden L. \& Melo I. 2014. Poroid fungi of Europe. Synopsis Fungorum 31. Fungiflora, Oslo.

Ryvarden L., Stokland J. \& Larsson K. H. 2003. A critical checklist of corticioid and poroid fungi of Norway. Synopsis Fungorum 17. Fungiflora, Oslo.

Spirin V., Miettinen O., Pennanen J., Kotiranta H. \& NieMELÄ T. 2013a. Antrodia hyalina, a new polypore from Russia, and A. leucaena, new to Europe. Mycol. Progr. 12: 53-61. 
Spirin V., Runnel K., VlasáK J., Miettinen O. \& PõldmaA K. 2015. Species diversity in the Antrodia crassa group (Polyporales, Basidiomycota). Fungal Biol. 119: 1291-1310.

Spirin V., Vlasá́ J., Niemelä T. \& Miettinen O. 2013b. What is Antrodia sensu stricto? Mycologia 105: 1555-1576.

Wu S. H., Yu Z. H., Chen C. T., Su C. H., Chen L. C., Hsu
W. C. \& Hwang G. Y. 2004. Taiwanofungus, a polypore new genus. Fungal Sci. 19: 109-116.

Yu Z. H., Wu S. H., Wang D. M. \& Chen C. T. 2010. Phylogenetic relationships of Antrodia species and related taxa based on analyses of nuclear large subunit ribosomal DNA sequences. Bot. Stud. (Taipei) 51: 53-60.

Received 22 March 2016 